\title{
The soluble guanylate cyclase stimulator riociguat: Evidence in pulmonary hypertension and beyond
}

Raymond Benza $^{1 *}$, Amresh Raina ${ }^{2}$, Manreet K. Kanwar ${ }^{3}$, Steven D. Nathan ${ }^{4}$, Stephen C. Mathai ${ }^{5}$

'Advanced Heart Failure, Transplant, Mechanical Circulatory Support and Pulmonary Hypertension Section, Allegheny Health Network, Pittsburgh, PA, USA ${ }^{2}$ Pulmonary Hypertension Program, Allegheny Health Network, Pittsburgh, PA, USA

${ }^{3}$ Chronic Thromboembolic Pulmonary Hypertension Program, Allegheny Health Network, Pittsburgh, PA, USA

${ }^{4}$ Advanced Lung Disease and Transplant Program, Inova Fairfax Hospital, Vienna, VA, USA

${ }^{5}$ Johns Hopkins University School of Medicine, Division of Pulmonary and Critical Care Medicine, Baltimore, MD, USA

Article Info

\section{Article Notes}

Received: August 11, 2017

Accepted: November 02, 2017

\section{*Correspondence:}

Prof. Raymond Benza

Professor of Medicine, Program Director Advanced Heart

Failure, Transplant, Mechanical Circulatory Support and

Pulmonary Hypertension Section, Allegheny Health Network,

Pittsburgh, PA 15212, USA; Email: raymond.benza@ahn.org

(c) 2017 Benza R. This article is distributed under the terms of the Creative Commons Attribution 4.0 International License.

\section{Keywords}

Soluble guanylate cyclase

Chronic thromboembolic pulmonary hypertension

Pulmonary arterial hypertension

Riociguat

Vericiguat

Heart failure

\section{ABSTRACT}

The soluble guanylate cyclase $(\mathrm{sGC}$ ) stimulators riociguat and vericiguat elevate intracellular cyclic guanosine monophosphate (cGMP) levels via stimulation of the nitric oxide-sGC-cGMP pathway resulting in vasodilatory, anti-inflammatory, anti-proliferative, and anti-fibrotic effects. Riociguat is approved for the treatment of pulmonary arterial hypertension (PAH) and inoperable or persistent/recurrent chronic thromboembolic pulmonary hypertension (CTEPH). Placebo-controlled phase 3 trials in both indications demonstrated significant improvements in exercise capacity, functional class, and pulmonary hemodynamics, with sustained efficacy and good tolerability in long-term open-label extension studies. Pilot or phase 2 studies of riociguat in pulmonary hypertension associated with heart failure (HF) or chronic obstructive pulmonary disease showed improvements in some hemodynamic parameters, although riociguat is contraindicated in pulmonary hypertension associated with idiopathic interstitial pneumonias. Riociguat is undergoing trials in other conditions including diffuse cutaneous systemic sclerosis. Vericiguat, a novel once-daily SGC stimulator, is well tolerated in patients with $\mathrm{HF}$ and is undergoing a phase 3 trial in $\mathrm{HF}$ with reduced ejection fraction. These ongoing studies will clarify the roles of sGC stimulators in indications beyond $\mathrm{PAH}$ and $\mathrm{CTEPH}$.

\section{Abbreviations}

6MWD: 6-minute walking distance; cGMP: cyclic guanosine monophosphate; CTEPH: chronic thromboembolic pulmonary hypertension; dcSSc: diffuse cutaneous systemic sclerosis; HF: heart failure; LVEF: left ventricular ejection fraction; mPAP: mean pulmonary artery pressure; NO: nitric oxide; NT-proBNP: $N$-terminal pro-brain natriuretic peptide; $\mathrm{PAH}$ : pulmonary arterial hypertension; PDE5: phosphodiesterase type 5; PEA: pulmonary endarterectomy; PH: pulmonary hypertension; PVR: pulmonary vascular resistance; RP: Raynaud's phenomenon; sGC: soluble guanylate cyclase; tid: three times daily; WHO: World Health Organization.

\section{Introduction}

Pulmonary hypertension (PH) is a broad term encompassing a variety of disorders, defined by a mean pulmonary artery pressure (mPAP) $\geq 25 \mathrm{mmHg}^{1}$. $\mathrm{PH}$ can lead to right ventricular dysfunction and failure and can eventually be fatal ${ }^{2,3}$. Globally, the prevalence of 
PH is estimated at approximately $1 \%$ of the population ${ }^{4}$. Based on etiology, PH is classified into five World Health Organization (WHO) groups ${ }^{5}$ :

Group 1: Pulmonary arterial hypertension (PAH), a category that contains several disorders/ subgroups, including idiopathic $\mathrm{PAH}$, heritable $\mathrm{PAH}$, and $\mathrm{PAH}$ associated with certain conditions such as connective tissue diseases (e.g. diffuse cutaneous systemic sclerosis ( $\mathrm{dcSSc})$ ), congenital heart disease (CHD), and human immunodeficiency virus infection. The definition of PAH includes pulmonary vascular resistance (PVR) $>3$ Wood units $\left(240 \mathrm{dyn} \cdot \mathrm{s} \cdot \mathrm{cm}^{-5}\right)$ and pulmonary capillary wedge pressure $\leq 15 \mathrm{mmHg}^{2}$

\section{Group 2: Left-heart-related PH}

\section{Group 3: Lung-/hypoxia-related PH}

Group 4: Chronic thromboembolic pulmonary hypertension (CTEPH)

\section{Group 5: PH with unclear/multifactorial etiology.}

$\mathrm{PH}$ in developing countries is often associated with CHD or infectious disease ${ }^{4}$. There has been a significant amount of recent research and drug development concentrated on PAH and CTEPH, which are both considered rare diseases and may share similar pathology ${ }^{4,6,7}$.

Riociguat (BAY-63-2521; Bayer AG, Wuppertal, Germany) is a soluble guanylate cyclase (sGC) stimulator approved for the treatment of PAH and inoperable or persistent/recurrent CTEPH. Currently, it is the only approved medical therapy for inoperable and persistent/ recurrent $\mathrm{CTEPH}^{8}$. sGC stimulators are a novel class of therapeutics with vasodilatory, anti-inflammatory, antiproliferative, and anti-fibrotic effects in various in vitro and in vivo models ${ }^{9-11}$. These diverse actions mean that sGC stimulators have the potential to treat many other diseases, including heart failure (HF), systemic sclerosis, and cystic fibrosis. This review discusses the clinical evidence for riociguat and another sGC stimulator, vericiguat (BAY 1021189; Bayer AG). Results are summarized in Table 1.

\section{The NO-sGC-cGMP pathway}

sGC is a key enzyme in the nitric oxide (NO) signaling pathway, which plays many roles in the control of the vascular system including regulation of vascular tone, inhibition of vascular smooth muscle cell proliferation, and protection against inflammation ${ }^{9,10}$. Impaired functioning of this system has been implicated in $\mathrm{PH}$, coronary artery disease, peripheral vascular disease, and atherosclerosis ${ }^{9,10}$. NO from vascular endothelial cells binds with sGC, which catalyzes the synthesis of the secondary messenger cyclic guanosine monophosphate (cGMP), and the pharmacologic effects of sGC stimulators result from their action to enhance cGMP synthesis ${ }^{12}$. cGMP, once produced, has multiple effects, mostly mediated through activation of protein kinase G. Activation of this kinase ultimately leads to vasodilation via activation of myosin phosphatase that releases calcium from smooth muscle cells. In addition, the NO-sGC-cGMP pathway mediates many physiologic functions including regulation of cell proliferation, platelet aggregation, and fibrosis ${ }^{13,14}$. Depletion of NO leads to a variety of abnormalities including pulmonary vasoconstriction, vascular remodeling, and in situ thrombosis. Reduction in endogenous NO levels has been observed in several types of $\mathrm{PH}^{9}$. sGC stimulators have a dual mode of action; specifically, they enhance the sGC response to endogenous $\mathrm{NO}$ and also directly stimulate sGC independent of NO via a different binding site, leading to elevation of cGMP (Figure 1$)^{8,12}$. This differs from phosphodiesterase type 5 (PDE5) inhibitors (another PAH-approved drug class), which prevent the breakdown of cGMP by occupying the catalytic site on PDE5. However, PDE5 inhibitors are dependent on cGMP synthesis and the presence of NO, a requirement that SGC stimulators circumvent ${ }^{15}$. Riociguat increases sGC activity by up to $112-$ fold ${ }^{16}$.

\section{Riociguat in PAH and CTEPH}

Riociguat was investigated in PATENT-1, a 12-week, double-blind, placebo-controlled trial in 443 patients with symptomatic PAH (ClinicalTrials.gov: NCT00810693). Patients received either placebo or riociguat (individually optimized doses up to $2.5 \mathrm{mg}$ three times daily (tid)). Riociguat significantly improved 6-minute walking distance (6MWD) (primary endpoint), PVR, $N$-terminal pro-brain natriuretic peptide (NT-proBNP), WHO functional class, and time to clinical worsening (secondary endpoints) compared with placebo in patients who were receiving no other treatment for the disease and those receiving endothelin-receptor antagonists (ERAs) or prostanoids ${ }^{17}$. In the open-label extension of this trial (PATENT-2; ClinicalTrials.gov: NCT00863681), the improvements in 6MWD, NT-proBNP, and WHO functional class with riociguat were maintained after 2 years, and riociguat was well tolerated as monotherapy or in combination with ERAs, prostanoids, or both ${ }^{18}$. In a subgroup of 35 patients in PATENT-1 with PAH associated with CHD, riociguat improved 6MWD, as well as NT-proBNP, WHO functional class, and PVR, compared with placebo ${ }^{19}$. The long-term outcome of patients in PATENT-1 and PATENT-2 with PH associated with connective tissue disease was similar to that seen in idiopathic $\mathrm{PAH}^{20}$.

CTEPH is characterized by obstruction of the pulmonary vasculature, usually as a consequence of unresolved pulmonary embolism ${ }^{21}$. Pulmonary endarterectomy (PEA) is a potentially curative surgery for CTEPH; however, not all patients are eligible and some have persistent and/or recurrent $\mathrm{PH}$ after surgery ${ }^{22}$. In addition, CTEPH frequently 
Table 1. Summary of clinical trials of sGC stimulators in PAH, CTEPH, other forms of PH, dcSSc, and HF.

\begin{tabular}{|c|c|c|c|}
\hline Study, population & Study design & Primary outcome & Other outcomes \\
\hline $\begin{array}{l}\text { PATENT- } 1^{17}(\text { NCT00810693) } \\
\text { PAH }(n=443)\end{array}$ & $\begin{array}{l}\text { 12-wk, DB, RCT. Riociguat } \\
\text { maximum dose } 1.5 \text { (exploratory) } \\
\text { or } 2.5 \mathrm{mg} \text { tid }\end{array}$ & $\begin{array}{l}6 \mathrm{MWD} \text { at Week } 12:-6 \pm 86 \mathrm{~m} \text { with } \\
\mathrm{PBO},+30 \pm 66 \mathrm{~m} \text { with riociguat: } \\
p<0.001\end{array}$ & $\begin{array}{l}\text { WHO FC, PVR, NT-proBNP, and clinical } \\
\text { worsening significantly improved vs } \\
\text { PBO }\end{array}$ \\
\hline $\begin{array}{l}\text { PATENT- } 2^{18} \\
\text { (NCT00863681) } \\
\text { PAH }(n=396)\end{array}$ & OL extension of PATENT-1 & $6 \mathrm{MWD}+47 \mathrm{~m}$ vs baseline at $2 \mathrm{yr}$ & $\begin{array}{l}\text { Improvements in NT-proBNP and } \\
\text { WHO FC maintained }\end{array}$ \\
\hline $\begin{array}{l}\text { CHEST- }{ }^{23}(\text { NCT00855465) } \\
\text { CTEPH }(n=261)\end{array}$ & $\begin{array}{l}\text { 16-wk, DB, RCT } \\
\text { Riociguat maximum dose } \\
2.5 \mathrm{mg} \text { tid }\end{array}$ & $\begin{array}{l}6 \mathrm{MWD} \text { at Week } 16:-6 \pm 84 \mathrm{~m} \text { with } \\
\mathrm{PBO},+39 \pm 79 \mathrm{~m} \text { with riociguat: } \\
p<0.001\end{array}$ & $\begin{array}{l}\text { WHO FC, PVR, and NT-proBNP } \\
\text { significantly improved vs PBO }\end{array}$ \\
\hline $\begin{array}{l}\text { CHEST- } 2^{24}(\text { NCT00910429) } \\
\text { CTEPH }(n=237)\end{array}$ & OL extension of CHEST-1 & $6 \mathrm{MWD}+50 \mathrm{~m}$ vs baseline at $2 \mathrm{yr}$ & $\begin{array}{l}\text { Improvements in NT-proBNP and } \\
\text { WHO FC maintained }\end{array}$ \\
\hline $\begin{array}{l}\text { RESPITE (NCT02007629) } \\
\text { PAH }(n=61)^{25}\end{array}$ & $\begin{array}{l}\text { 24-wk, OL, multicenter, } \\
\text { uncontrolled } \\
\text { Patients with inadequate } \\
\text { response to PDE5i }\end{array}$ & $\begin{array}{l}6 \mathrm{MWD}+31 \mathrm{~m} \text { vs baseline at } \\
\text { Week 24: } p=0.001 \\
\text { (All endpoints were exploratory) }\end{array}$ & $\begin{array}{l}\text { WHO FC and NT-proBNP significantly } \\
\text { improved vs baseline } \\
\text { (All endpoints were exploratory) }\end{array}$ \\
\hline $\begin{array}{l}\text { LEPHT }^{26}(\mathrm{NCT01065454)} \\
\text { PH-sLVD }(\mathrm{n}=201)\end{array}$ & $\begin{array}{l}\text { 16-wk, DB, RCT } \\
\text { Riociguat } 0.5,1.0 \text {, or } 2.0 \mathrm{mg} \text { tid }\end{array}$ & $\begin{array}{l}\text { mPAP PBO-corrected mean difference } \\
-2.7 \mathrm{mmHg}: p=0.10\end{array}$ & $\begin{array}{l}\text { Significantly improved cardiac index } \\
(p=0.0018) \text { and PVR }(p=0.03)\end{array}$ \\
\hline $\begin{array}{l}\text { DILATE- }{ }^{29} \text { (NCT01172756) } \\
\text { PH-diastolic HF }(n=39)\end{array}$ & $\begin{array}{l}\text { 16-wk, DB, RCT } \\
\text { Riociguat single dose } 0.5,1.0 \text {, or } \\
2.0 \mathrm{mg}\end{array}$ & $\begin{array}{l}\text { mPAP: }-6.3 \pm 4.2 \mathrm{mmHg} \text { with } \mathrm{PBO}, \\
-5.1 \pm 4.7 \mathrm{mmHg} \text { with riociguat } \\
2.0 \mathrm{mg}: \mathrm{p}=0.60\end{array}$ & $\begin{array}{l}\text { Riociguat } 2.0 \text { mg significantly } \\
\text { increased SV }(p=0.04) \text { and decreased } \\
\text { SBP }(p=0.03) \text { and RV end-diastolic } \\
\text { area }(p=0.04)\end{array}$ \\
\hline $\begin{array}{l}\text { Ghofrani et al } 2015^{31} \\
\text { (NCT00640315) } \\
\text { PH-COPD }(n=22)\end{array}$ & $\begin{array}{l}\text { Non-randomized, non-blinded, } \\
\text { non-controlled pilot } \\
\text { Riociguat single dose } 1.0 \text { or } 2.5 \mathrm{mg}\end{array}$ & $\begin{array}{l}\text { mPAP: }-4.8 \pm 4.17 \mathrm{mmHg} \text { with } 2.5 \mathrm{mg} \\
\text { vs baseline: } p=0.002\end{array}$ & $\begin{array}{l}\text { PVR: }-123.8 \pm 73.53 \text { dyn } \cdot s \cdot \mathrm{cm}^{-5} \text { with } \\
2.5 \mathrm{mg} \text { vs baseline: } p=0.0002\end{array}$ \\
\hline $\begin{array}{l}\text { Hoeper et al 2013 } \\
\text { (NCT00694850) } \\
\text { PH-ILD }(n=22)\end{array}$ & $\begin{array}{l}\text { Non-randomized, non-blinded, } \\
\text { non-controlled pilot. Riociguat } \\
\text { target dose } 2.5 \mathrm{mg} \text { tid }\end{array}$ & $\begin{array}{l}\text { Safety and tolerability: generally well } \\
\text { tolerated }\end{array}$ & $\begin{array}{l}\text { Increased mean cardiac output and } \\
\text { decreased PVR }\end{array}$ \\
\hline $\begin{array}{l}\text { RISE-IIP33 (NCT02138825) } \\
\text { PH-IIP ( } n=147)\end{array}$ & 26-wk, DB, RCT & Trial terminated & \\
\hline $\begin{array}{l}\text { RISE-SSc }{ }^{42 a} \text { (NCT02283762) } \\
\text { dcSSc }\end{array}$ & 52-wk, DB, RCT & Trial ongoing & \\
\hline $\begin{array}{l}\operatorname{DIGIT}^{45}(\mathrm{NCT} 01926847) \\
\operatorname{RP}(\mathrm{n}=20)\end{array}$ & $\begin{array}{l}\text { Single dose, DB, RCT } \\
\text { Riociguat } 2.0 \mathrm{mg}\end{array}$ & $\begin{array}{l}\text { Digital blood flow (room } \\
\text { temperature): }+41 \% \text { with riociguat at } \\
2 \text { hours }\end{array}$ & $\begin{array}{l}\text { Digital blood flow (cold): }+15 \% \text { with } \\
\text { riociguat at } 2 \text { hours }\end{array}$ \\
\hline $\begin{array}{l}\text { Rio-CF (NCT02170025) } \\
\text { CF (Phe508del mutation) }\end{array}$ & $\mathrm{DB}, \mathrm{RCT}$ & Trial terminated & \\
\hline $\begin{array}{l}\text { SOCRATES-REDUCED }{ }^{50} \\
\text { (NCT01951625) } \\
\text { HF reduced LVEF }(n=456)\end{array}$ & $\begin{array}{l}\text { 12-wk, DB, RCT } \\
\text { Vericiguat } 1.25,2.5,5.0 \text {, or } \\
10.0 \mathrm{mg}\end{array}$ & $\begin{array}{l}\text { Ratio of geometric mean NT-proBNP } \\
\text { vs PBO } 0.885 ; p=0.15\end{array}$ & $\begin{array}{l}\text { Dose-dependent effect of vericiguat } \\
\text { on NT-proBNP }(p<0.02)\end{array}$ \\
\hline $\begin{array}{l}\text { SOCRATES-PRESERVED } 52,53 \\
\text { (NCT01951638) HF } \\
\text { preserved LVEF }(n=447)\end{array}$ & $\begin{array}{l}\text { 12-wk, DB, RCT } \\
\text { Vericiguat } 1.25 \text { or } 2.5 \mathrm{mg} \text { fixed } \\
\text { dose or titrated to } 5.0 \text { or } \\
10.0 \mathrm{mg}\end{array}$ & $\begin{array}{l}\text { Difference in log NT-proBNP vs PBO } \\
0.14 ; p=0.20 \\
\text { Difference in LAV vs PBO } 1.6 \mathrm{~mL} ; \\
p=0.37\end{array}$ & $\begin{array}{l}\text { Quality of life improvement at highest } \\
\text { dose }\end{array}$ \\
\hline
\end{tabular}

Abbreviations: 6MWD: 6-minute walking distance; CF: cystic fibrosis; COPD: chronic obstructive pulmonary disease; CTEPH: chronic thromboembolic pulmonary hypertension; DB: double-blind; dcSSc: diffuse cutaneous systemic sclerosis; HF: heart failure; IIP: idiopathic interstitial pneumonias; ILD: interstitial lung disease; LAV: left atrial volume; LVEF: left ventricular ejection fraction; mPAP: mean pulmonary artery pressure; NT-proBNP: $N$-terminal pro-brain natriuretic peptide; OL: open-label; PAH: pulmonary arterial hypertension; PBO: placebo; PDE5i: phosphodiesterase type 5 inhibitor; PH: pulmonary hypertension; PVR: pulmonary vascular resistance; RCT: randomized controlled trial; RP: Raynaud's phenomenon; RV: right ventricular; SBP: systolic blood pressure; sGC: soluble guanylate cyclase; sLVD: systolic left ventricular dysfunction; SV: stroke volume; tid: three times daily; wk: week; WHO FC: World Health Organization functional class; yr: years Outcome values are means \pm standard deviation unless otherwise stated.

involves pulmonary small-vessel disease not amenable to PEA $^{21}$. Riociguat was investigated in CHEST-1, a 16-week, double-blind, placebo-controlled trial in 261 patients with CTEPH who were ineligible for PEA or experienced persistent and/or recurrent PH after PEA (ClinicalTrials. gov: NCT00855465). Patients received placebo or riociguat (individual optimized doses up to $2.5 \mathrm{mg}$ tid). Riociguat significantly improved 6MWD (primary endpoint), PVR, NTproBNP, and WHO functional class compared with placebo ${ }^{23}$. In the open-label extension (CHEST-2; ClinicalTrials. 
(a)

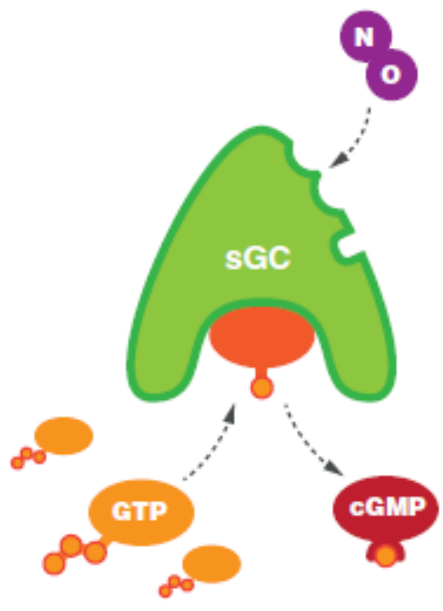

(b)

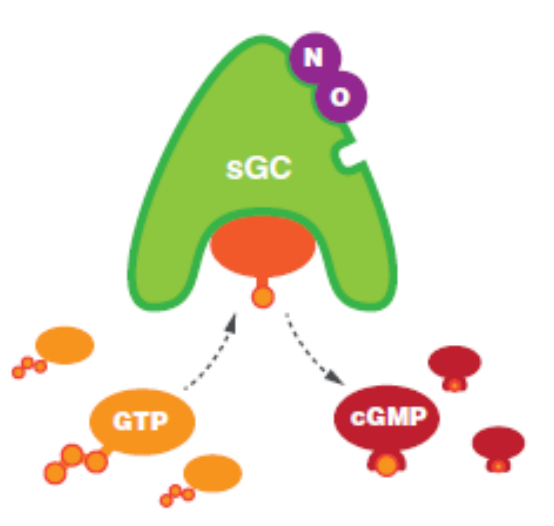

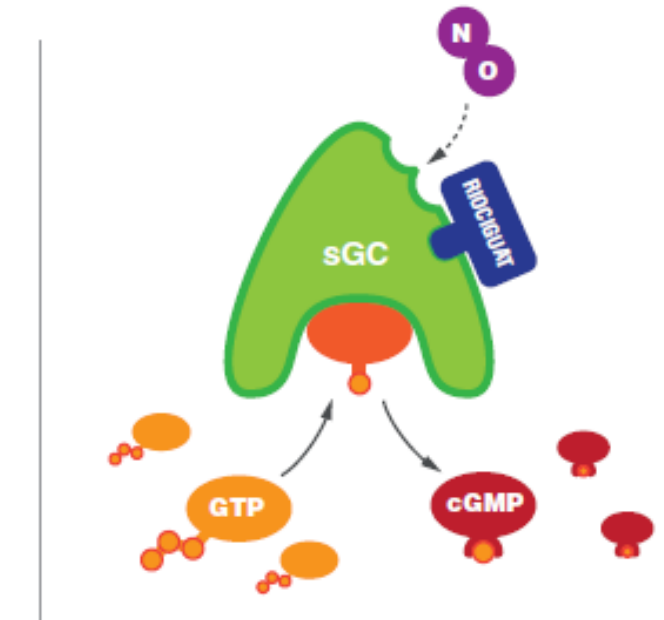

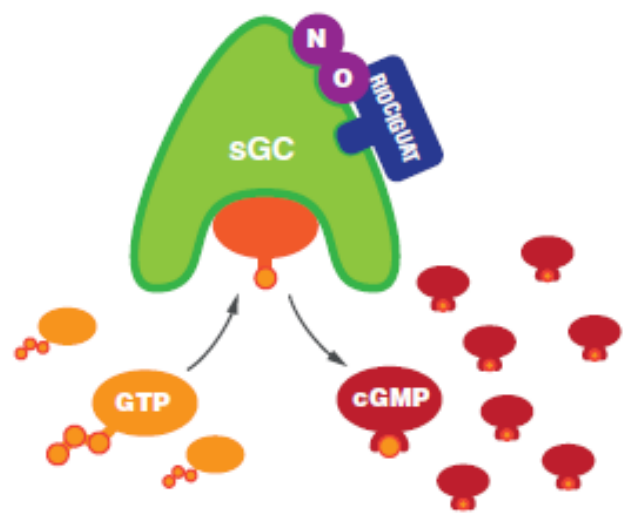

Figure 1: Mechanism of action of riociguat ${ }^{8,12}$. (a) Riociguat directly stimulates SGC in an NO-independent manner. (b) Riociguat sensitizes $\mathrm{SGC}$ to endogenous NO by stabilizing binding of the molecules.

CGMP: cyclic guanosine monophosphate; GTP: guanosine triphosphate; NO: nitric oxide; sGC: soluble guanylate cyclase.

Original figure based on cited references.

gov: NCT00910429), the improvements in 6MWD, NT-proBNP, and WHO functional class were maintained after 2 years, and riociguat was well tolerated and exhibited a good safety profile ${ }^{24}$.

PDE5 inhibitors are widely used in the treatment of PAH but some patients do not attain treatment goals with these agents. A 24-week, open-label, uncontrolled trial (RESPITE; ClinicalTrials.gov: NCT02007629) has indicated that selected patients with PAH and an unsatisfactory response to PDE5 inhibitors may benefit from switching to riociguat ${ }^{25}$.

\section{Riociguat in other forms of PH}

\section{Group 2.1: PH associated with HF with reduced ejection fraction}

$\mathrm{PH}$ resulting from $\mathrm{HF}$ with left ventricular systolic dysfunction is associated with high morbidity and mortality, and established therapies do not improve the associated $\mathrm{PH}^{2}$. LEPHT, a 16-week, double-blind, placebo-controlled, phase $2 \mathrm{~b}$ trial in 201 patients with $\mathrm{PH}$ associated with $\mathrm{HF}$ and left ventricular ejection fraction (LVEF) $\leq 40 \%$, randomized patients to placebo or riociguat (0.5, 1.0, or $2.0 \mathrm{mg}$ tid (ClinicalTrials.gov: NCT01065454)). There was a non-significant $(\mathrm{p}=0.1)$ decrease in mPAP with riociguat $2 \mathrm{mg}$ versus placebo (primary endpoint). PVR was significantly reduced and cardiac index significantly increased with riociguat, which was well tolerated ${ }^{26}$.

\section{Group 2.2: PH associated with HF with preserved ejection fraction}

Up to half of patients with HF have preserved LVEF, with most patients developing $\mathrm{PH}$ for which there is no proven therapy ${ }^{2,27}$. Reduced cGMP has been observed in these patients ${ }^{28}$, therefore targeting the NO-sGC-cGMP pathway 
is logical. DILATE-1, a single-dose, double-blind, placebocontrolled, parallel-group, phase $2 \mathrm{a}$ trial in 39 patients with $\mathrm{PH}$ associated with $\mathrm{HF}$ and $\mathrm{LVEF}>50 \%$, randomized patients to placebo or riociguat $(0.5,1.0 \text {, or } 2.0 \mathrm{mg})^{29}$ (ClinicalTrials.gov: NCT01172756). The decrease in mPAP from baseline to 6 hours (primary endpoint) did not differ significantly with riociguat $2 \mathrm{mg}$ versus placebo but other hemodynamic endpoints were improved (Table 1) and riociguat was well tolerated ${ }^{29}$.

\section{Group 3.1: PH associated with chronic obstructive pulmonary disease}

The prognosis of severe chronic obstructive pulmonary disease (COPD) associated with PH is poor ${ }^{30}$. In a singledose pilot study (ClinicalTrials.gov: NCT00640315) in 22 patients with $\mathrm{PH}$ associated with COPD, riociguat (1.0 or $2.5 \mathrm{mg}$ ) was associated with significant improvements in mPAP and PVR, and was well tolerated ${ }^{31}$.

\section{Group 3.2: PH associated with interstitial lung disease}

Two trials have assessed the effect of riociguat in patients with $\mathrm{PH}$ associated with interstitial lung disease (ILD). In an open-label, uncontrolled, pilot study (ClinicalTrials.gov: NCT00694850) in 22 patients, riociguat (1.0-2.5 mg tid) was generally well tolerated, with increases in mean cardiac output and decreases in $\mathrm{PVR}^{32}$. However, a phase 2, 26-week, placebo-controlled, double-blind randomized controlled trial in 147 patients with $\mathrm{PH}$ associated with idiopathic interstitial pneumonias (PH-IIP) - a distinct subset of ILD-(RISE-IIP; ClinicalTrials.gov: NCT02138825) was

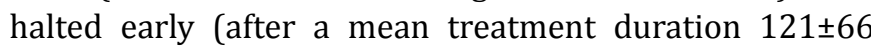
days) due to an excess of deaths and serious adverse events with riociguat compared with placebo as well as a lack of efficacy $^{33}$. Riociguat is therefore contraindicated in $\mathrm{PH}$ IIP $^{34,35}$.

\section{Riociguat in non-PH disorders}

\section{Diffuse cutaneous systemic sclerosis}

DcSSc is a rare but incapacitating and life-threatening form of systemic sclerosis characterized by progressive fibrosis of the skin and internal organs resulting from deposition of extracellular matrix ${ }^{36-38}$. DcSScis characterized by early-onset organ involvement and a mortality of almost $50 \%$ at 10 years $^{39}$. Leading causes of death in patients with systemic sclerosis include pulmonary fibrosis and $\mathrm{PAH}^{40}$.

Studies in several animal models have demonstrated that riociguat has anti-fibrotic effects $^{41,42}$, and a subgroup analysis of PATENT-1 and -2 reported that riociguat was well tolerated and associated with long-term improvements in 6MWD and other endpoints in patients with $\mathrm{PAH}$ associated with connective tissue disease ${ }^{20}$. These observations may suggest a potential benefit for riociguat in dcSSc. Moreover, dcSSc is characterized by small-vessel vasculopathy, caused in part by upregulation of endothelin and reduced NO levels, leading to decreased levels of cGMP ${ }^{38}$. Elevation of cGMP by riociguat could therefore be beneficial in this condition. RISE-SSc is an ongoing, 52-week, double-blind, placebo-controlled, phase 2 trial investigating the efficacy and safety of riociguat in patients with dcSSc${ }^{42 a}$. The recruitment target is approximately 130 patients (ClinicalTrials.gov: NCT02283762).

\section{Raynaud's phenomenon}

Raynaud's phenomenon (RP) is a cold- or stresstriggered digital ischemia caused by vasoconstriction in the digital blood vessels sometimes associated with systemic sclerosis ${ }^{43}$. Medical therapy for RP is unsatisfactory, with many patients notresponding ${ }^{44}$. The efficacy and tolerability of riociguat in RP were investigated in DIGIT, a single-dose (2 mg), double-blind, placebo-controlled, cross-over trial in 20 patients (ClinicalTrials.gov: NCT01926847). Two hours after administration, riociguat increased mean digital blood flow versus baseline by $41 \%$ at room temperature and by $15 \%$ after cold water exposure, and 12 (60\%) patients responded to treatment (response defined as an increase of $\geq 10 \%$ in digital blood flow at room temperature or after cold water exposure) $)^{45}$.

\section{Cystic fibrosis}

Phe508del is a specific mutation of the gene for the protein cystic fibrosis transmembrane conductance regulator (CFTR) and the most common cause of cystic fibrosis $(\mathrm{CF})^{46}$. Preclinical data have suggested that riociguat may improve CFTR channel function. The Rio-CF phase 2 trial assessed safety, tolerability, and early signs of efficacy of riociguat in patients with CF homozygous for Phe508del with mild-to-moderate disease (ClinicalTrials. gov: NCT02170025). After completion of part 1, the study has been terminated. Based on multiple factors, the design of part 2 is no longer appropriate. There were no safety concerns identified.

\section{Vericiguat in $\mathrm{HF}$}

In patients with $\mathrm{HF}$, endothelial dysfunction and reactive oxygen species reduce NO levels and bioavailability, resulting in insufficient stimulation of $\mathrm{SGC}$ and a reduction in cGMP synthesis. cGMP is essential for normal cardiac and vascular function. In HF, reduced NO-sGC-cGMP signaling results in vasoconstriction, vascular stiffness, adverse remodeling, and decreased renal and coronary blood flow with increased organ impairment ${ }^{47-49}$. Restoration of NO-sGC-cGMP signaling is a promising approach for the treatment of HF and one that is not directly addressed by current standard of care (angiotensin-converting enzyme inhibitors, angiotensin receptor blockers, mineralocorticoid receptor antagonists, or beta-blockers). Vericiguat, a novel 
sGC stimulator with optimized pharmacokinetic properties allowing once-daily dosing, has been investigated in patients with HF. SOCRATES-REDUCED (ClinicalTrials.gov: NCT01951625) was a 12-week, double-blind, placebocontrolled, dose-finding, phase 2 trial in 456 patients with worsening chronic $\mathrm{HF}$ and reduced $\mathrm{LVEF}(<45 \%)^{50}$. Patients were randomized to placebo or vericiguat once daily $(1.25$, $2.5,5.0$, or $10.0 \mathrm{mg}$ ). Vericiguat was well tolerated but had no significant effect on the primary endpoint, NT-proBNP levels, compared with placebo. However, secondary analysis suggested a dose-response relationship whereby higher vericiguat doses were associated with greater reductions in NT-proBNP level ${ }^{50}$. Based on these results, a large phase 3 clinical outcome trial of vericiguat in patients with LVEF $<45 \%$ is recruiting (VICTORIA). The study is designed to test whether vericiguat is superior to placebo (each on top of standard of care) in increasing the time to first occurrence of the composite of cardiovascular death or HF hospitalization. This trial is expected to be completed in 2020 (ClinicalTrials.gov: NCT02861534) ${ }^{51}$.

SOCRATES-PRESERVED (ClinicalTrials.gov: NCT01951638) was a 12 -week, double-blind, placebo-controlled phase $2 \mathrm{~b}$ trial in 447 patients with symptomatic worsening chronic HF and $\mathrm{LVEF} \geq 45 \%$. Patients were randomized to placebo or vericiguat once daily $(1.25,2.5,2.5-5.0 \text {, or } 2.5-10.0 \mathrm{mg})^{52}$. Vericiguat was well tolerated, but there was no significant difference from placebo for change in NT-proBNP from baseline or left atrial volume at 12 weeks (primary endpoints). However, at the highest dose vericiguat was associated with quality of life improvements from baseline ${ }^{52}$. A larger proportion of patients treated with vericiguat, $10 \mathrm{mg}$, achieved clinically meaningful improvements in the Kansas City Cardiomyopathy Questionnaire Clinical Summary Score (KCCQ-CSS) and the 5-dimension EuroQol Questionnaire (EQ-5D) score, and a dosedependent relationship was observed ${ }^{52,53}$.

\section{Summary}

Riociguat was the first drug to demonstrate efficacy and tolerability in two separate $\mathrm{PH}$ indications, namely $\mathrm{PAH}$ and inoperable or persistent/recurrent $\mathrm{CTEPH}^{17}$, $18,23,24$. This raised the possibility that SGC stimulators may have efficacy in other forms of PH. Initial trials in $\mathrm{PH}$ associated with $\mathrm{HF}$ with reduced or preserved left ventricular systolic function or COPD $^{26,29,31}$, although with mixed results in terms of achieving their primary endpoints, did give signals which warrant further welldesigned investigations in this area. In a subgroup of patients with PH-IIP, riociguat may be harmful and its use in this disease subset is contraindicated.

The involvement of the NO-sGC-cGMP pathway in many diseases suggests that sGC stimulators could have diverse benefits. For riociguat this supposition is supported by its established indications (PAH and CTEPH) $)^{17,18,23,24}$ and early results in $\mathrm{RP}^{45}$, and it is under investigation in dcSSc.
Vericiguat is well tolerated in patients with $\mathrm{HF}^{50,52,53}$, and a phase 3 trial of this agent in HF with reduced ejection fraction is in progress ${ }^{51}$. Ongoing and future trials will clarify the clinical roles of sGC stimulators.

\section{Acknowledgements}

Editorial support for this review was provided by Adelphi Communications Ltd, Bollington, UK supported by Bayer AG.

\section{Conflicts of interest}

Raymond Benza reports grant support from Belleraphon, Actelion, Eiger, and Bayer AG.

Amresh Raina reports speaker fees from Bayer AG.

Manreet K. Kanwar is on a Speakers' Bureau and Advisory Board for Bayer AG.

Steven D. Nathan has received consulting fees and Inova Fairfax Hospital has received research funding from Bayer $\mathrm{AG}$ for work pertaining to a clinical trial of riociguat.

Stephen C. Mathai reports:

- Consultancies in the past 2 years: Actelion, Bayer AG, and United Therapeutics

- Grants: NIH/NHLBI and Scleroderma Foundation

- Associations: Pulmonary Hypertension Association Scientific Leadership Council.

\section{References}

1. Hoeper MM, Bogaard HJ, Condliffe R, et al.. Definitions and diagnosis of pulmonary hypertension. J Am Coll Cardiol. 2013; 62(25 Suppl): D42-D50.

2. Galiè, N. Humbert M, Vachiery JL, et al. 2015 ESC/ERS Guidelines for the diagnosis and treatment of pulmonary hypertension: The Joint Task Force for the Diagnosis and Treatment of Pulmonary Hypertension of the European Society of Cardiology (ESC) and the European Respiratory Society (ERS): Endorsed by: Association for European Paediatric and Congenital Cardiology (AEPC), International Society for Heart and Lung Transplantation (ISHLT). Eur Respir J. 2015; 46(4): p. 903-975.

3. Schermuly RT, Ghofrani HA, Wilkins MR, et al. Mechanisms of disease: pulmonary arterial hypertension. Nat Rev Cardiol. 2011; 8(8): p. 443455 .

4. Hoeper MM, Humbert M, Souza R, et al. A global view of pulmonary hypertension. Lancet Respir Med. 2016; 4(4): p. 306-322.

5. Simonneau, G, Gatzoulis MA, Adatia I, et al. Updated clinical classification of pulmonary hypertension. J Am Coll Cardiol. 2013; 62(25 Suppl.): p. D34-D41.

6. McGoon MD, Benza RL, Escribano-Subias P, et al. Pulmonary arterial hypertension: epidemiology and registries. J Am Coll Cardiol. 2013; 62(25 Suppl): p. D51-D59.

7. Lang I. Chronic thromboembolic pulmonary hypertension: a distinct disease entity. Eur Respir Rev. 2015; 24(136): p. 246-252.

8. Ghofrani HA, Humbert M, Langleben D, et al. Riociguat: mode of action and clinical development in pulmonary hypertension. Chest. 2017; 151(2): p. 468-480. 
9. Stasch JP, Evgenov OV. Soluble guanylate cyclase stimulators in pulmonary hypertension. Handb Exp Pharmacol. 2013; 218: p. 279313.

10. Stasch JP, Pacher P, Evgenov OV. Soluble guanylate cyclase as an emerging therapeutic target in cardiopulmonary disease. Circulation. 2011; 123(20): p. 2263-2273

11. Dees C, Beyer C, Distler A, et al. Stimulators of soluble guanylate cyclase (sGC) inhibit experimental skin fibrosis of different aetiologies. Ann Rheum Dis. 2015; 74(8): p. 1621-1625.

12. Kim NH. Riociguat: an upcoming therapy in chronic thromboembolic pulmonary hypertension? Eur Respir Rev. 2010; 19(115): p. 68-71.

13. Klinger JR, Abman SH, Gladwin MT. Nitric oxide deficiency and endothelial dysfunction in pulmonary arterial hypertension. Am J Respir Crit Care Med. 2013; 188(6): p. 639-646.

14. Sandner P, Stasch J. Anti-fibrotic effects of soluble guanylate cyclase stimulators and activators: a review of the preclinical evidence. Respir Med. 2017; 122(Suppl 1): p. S1-S9.

15. Humbert M, Ghofrani HA. The molecular targets of approved treatments for pulmonary arterial hypertension. Thorax. 2016; 71(1): p. 73-83.

16. Schermuly RT, Stasch JP, Pullamsetti SS, et al. Expression and function of soluble guanylate cyclase in pulmonary arterial hypertension. Eur Respir J. 2008; 32(4): p. 881-891.

17. Ghofrani HA, Galiè N, Grimminger F, et al. Riociguat for the treatment of pulmonary arterial hypertension. N Engl J Med. 2013; 369(4): 330340.

18. Ghofrani HA, Grimminger F, Grünig E, et al. Predictors of long-term outcomes in patients treated with riociguat for pulmonary arterial hypertension: data from the PATENT-2 open-label, randomised, longterm extension trial. Lancet Respir Med. 2016; 4(5): p. 361-371.

19. Rosenkranz S, Ghofrani HA, Beghetti M, et al. Riociguat for pulmonary arterial hypertension associated with congenital heart disease. Heart. 2015; 101(22): p. 1792-1799.

20. Humbert M, Coghlan JG, Ghofrani HA, et al. Riociguat for the treatment of pulmonary arterial hypertension associated with connective tissue disease: results from PATENT-1 and PATENT-2. Ann Rheum Dis. 2017; 76(2): p. $422-426$

21. Simonneau G, Torbicki A, Dorfmüller P, et al. The pathophysiology of chronic thromboembolic pulmonary hypertension. Eur Respir Rev. 2017; 26(143). pii: 160112. doi: 10.1183/16000617.0112-2016

22. Pepke-Zaba J, Ghofrani HA, Hoeper M. Medical management of chronic thromboembolic pulmonary hypertension. Eur Respir Rev. 2017; 26(143). pii: 160107. doi: 10.1183/16000617.0107-2016.

23. Ghofrani HA, D'Armini AM, Grimminger F, et al. Riociguat for the treatment of chronic thromboembolic pulmonary hypertension. $\mathrm{N}$ Engl J Med. 2013; 369(4): p. 319-329.

24. Simonneau G, D'Armini AM, Ghofrani HA, et al. Predictors of longterm outcomes in patients treated with riociguat for chronic thromboembolic pulmonary hypertension: data from the CHEST-2 open-label, randomised, long-term extension trial. Lancet Respir Med. 2016; 4(5): p. 372-380.

25. Hoeper MM, Simonneau G, Corris PA, et al. RESPITE: switching to riociguat in PAH patients with inadequate response to PDE5i. Eur Respir J. 2017; 50(3): pii 1602425. doi: 10.1183/13993003.024252016.

26. Bonderman D, Ghio S, Felix SB, et al. Riociguat for patients with pulmonary hypertension due to systolic left ventricular dysfunction: a phase IIb double-blind, randomized, placebo-controlled, doseranging hemodynamic study. Circulation. 2013; 128(5): p. 502-511.

27. Bursi F, McNallan SM, Redfield MM, et al. Pulmonary pressures and death in heart failure: a community study. J Am Coll Cardiol. 2012; 59(3): p. 222-231.

28. van Heerebeek L, Hamdani N, Falcão-Pires I, et al. Low myocardial protein kinase $\mathrm{G}$ activity in heart failure with preserved ejection fraction. Circulation. 2012; 126(7): p. 830-839.

29. Bonderman D, Pretsch I, Steringer-Mascherbauer R, et al. Acute hemodynamic effects of riociguat in patients with pulmonary hypertension associated with diastolic heart failure (DILATE-1): a randomized, double-blind, placebo-controlled, single-dose study. Chest. 2014; 146(5): p. 1274-1285.

30. Cuttica MJ, Kalhan R, Shlobin OA, et al. Categorization and impact of pulmonary hypertension in patients with advanced COPD. Respir Med. 2010; 104(12): p. 1877-1882.

31. Ghofrani HA, Staehler G, Grünig E, et al. Acute effects of riociguat in borderline or manifest pulmonary hypertension associated with chronic obstructive pulmonary disease. Pulm Circ. 2015; 5(2): p. 296-304.

32. Hoeper MM, Halank M, Wilkens $H$, et al. Riociguat for interstitial lung disease and pulmonary hypertension: a pilot trial. Eur Respir J. 2013; 41(4): p. 853-860.

33. Nathan S, Behr J, Collard H, et al. Riociguat for the treatment of pulmonary hypertension associated with idiopathic interstitial pneumonia. European Respiratory Society International Congress Milan, Italy, 9-13 September 2017. OA1985.

34. Bayer AG. Adempas (riociguat tablets): EU summary of product characteristics. 2017 [cited 2017 6th October]; Available from: http://www.ema.europa.eu/docs/en_GB/document_library/EPAR_Product_Information/human/002737/WC500165034.pdf.

35. Bayer AG. Highlights of prescribing information: ADEMPAS (riociguat) tablets, for oral use [cited 2017 6th October ]; Available from: http:// labeling.bayerhealthcare.com/html/products/pi/Adempas_PI.pdf.

36. Herrick AL, Pan X, Peytrignet S, et al. Treatment outcome in early diffuse cutaneous systemic sclerosis: the European Scleroderma Observational Study (ESOS). Ann Rheum Dis. 2017; 76(6), p. 1207-1218.

37. Denton CP, Khanna D. Systemic sclerosis. Lancet. 2017; 390(10103): p. 1685-1699.

38. Pattanaik D, Brown M, Postlethwaite BC, et al. Pathogenesis of systemic sclerosis. Front Immunol. 2015; 6:272.

39. Rubio-Rivas M, Royo C, Simeón CP, et al. Mortality and survival in systemic sclerosis: systematic review and meta-analysis. Semin Arthritis Rheum. 2014; 44(2): p. 208-219.

40. Tyndall AJ, Bannert B, Vonk M, et al. Causes and risk factors for death in systemic sclerosis: a study from the EULAR Scleroderma Trials and Research (EUSTAR) database. Ann Rheum Dis. 2010; 69(10): p. 18091815.

41. Sharkovska Y, Kalk P, Lawrenz B, et al. Nitric oxide-independent stimulation of soluble guanylate cyclase reduces organ damage in experimental low-renin and high-renin models. J Hypertens. 2010; 28(8): p. 1666-1675.

42. Geschka S, Kretschmer A, Sharkovska Y, et al. Soluble guanylate cyclase stimulation prevents fibrotic tissue remodeling and improves survival in salt-sensitive Dahl rats. PLoS One. 2011; 6(7): p. e21853.

42a. Distler 0, Pope J, Denton C, et al. RISE-SSc: riociguat in diffuse cuntaneous systemic sclerosis. Respir Med 2017;122(Suppl.):S14-S17.

43. Fardoun MM, Nassif J, Issa K, et al. Raynaud's phenomenon: a brief review of the underlying mechanisms. Front Pharmacol. 2016; 7: 438.

44. Ennis H, Hughes M, Anderson ME, et al. Calcium channel blockers for primary Raynaud's phenomenon. Cochrane Database Syst Rev. 2016; 2: p. CD002069.

45. Huntgeburth M, Kießling, Weimann G, et al. The sGC-stimulator riociguat for the treatment of Raynaud's phenomenon: a single-dose, 
double-blind, randomized, placebo-controlled, cross-over study (DIGIT). BMC Pharmacol Toxicol. 2015; 16(Suppl 1): p. A58.

46. Bobadilla JL, Macek M Jr, Fine JP, et al. Cystic fibrosis: a worldwide analysis of CFTR mutations--correlation with incidence data and application to screening. Hum Mutat. 2002; 19(6): p. 575-606.

47. Gheorghiade M, Marti CN, Sabbah HN, et al. Soluble guanylate cyclase: a potential therapeutic target for heart failure. Heart Fail Rev. 2013; 18(2): p. 123-134.

48. Breitenstein S, Roessig L, Sandner P, et al. Novel sGC stimulators and sGC activators for the treatment of heart failure. Handb Exp Pharmacol. 2017; 243: p. 225-247.

49. Marti CN, Gheorghiade M, Kalogeropoulos AP, et al. Endothelial dysfunction, arterial stiffness, and heart failure. J Am Coll Cardiol. 2012; 60(16): p. 1455-1469.

50. Gheorghiade M, Greene SJ, Butler J, et al. Effect of vericiguat, a soluble guanylate cyclase stimulator, on natriuretic peptide levels in patients with worsening chronic heart failure and reduced ejection fraction: the SOCRATES-REDUCED randomized trial. JAMA. 2015; 314(21): p. 2251-2262.

51. Armstrong PW, Roessig L, Patel MJ, et al. A multicenter, randomized, double-blind, placebo-controlled trial of the efficacy and safety of the oral soluble guanylate cyclase stimulator: the VICTORIA trial. JACC Heart Fail. 2017. pii: S2213-1779(17)30562-0. doi: 10.1016/ jchf.2017.08.013. [Epub ahead of print.]

52. Pieske B, Maggioni AP, Lam CSP, et al. Vericiguat in patients with worsening chronic heart failure and preserved ejection fraction: results of the SOluble guanylate Cyclase stimulatoR in heArT failurE patientS with PRESERVED EF (SOCRATES-PRESERVED) study. Eur Heart J. 2017; 38(15): p. 1119-1127.

53. Filippatos G, Maggioni AP, Lam CSP, et al. Patient-reported outcomes in the Soluble guanylate Cyclase stimulatoR in heArT failure patients with PRESERVED ejection fraction (SOCRATES-PRESERVED) study. Eur J Heart Fail. 2017; 19(6): p. 782-791. 